\title{
Occurrence of Bartonella genotypes in bats and associated Streblidae flies from Maranhão state, northeastern Brazil
}

\author{
Ocorrência de genótipos de Bartonella em morcegos e moscas Streblidae no \\ Estado do Maranhão, Nordeste do Brasil
}

\begin{abstract}
Maria do Socorro Costa Oliveira Braga'; Luiz Ricardo Gonçalves²; Thiago Merighi Vieira da Silva²; Francisco Borges Costa1; José Gomes Pereira'; Larissa Sarmento dos Santos'; Alcina Vieira de Carvalho Neta'; Roberto Carlos Negreiros de Arruda'; Eric Takashi Kamakura de Carvalho Mesquita'; Daniel Prazeres Chaves'; Ferdinan Almeida Melo'; Jady Lima Lopes'; Rayra Tayla Barbosa Martins'; Mauricio Souza Lima; Renan Bressianini do Amaral2; Rosangela Zacarias Machado²; Marcos Rogério Andréz* (D)

${ }^{1}$ Universidade Estadual do Maranhão - UEMA, São Luís, MA, Brasil

${ }^{2}$ Laboratório de Imunoparasitologia, Departamento de Patologia, Reprodução e Saúde Única, Faculdade de Ciências Agrárias e Veterinárias - FCAV, Universidade Estadual Paulista “Júlio de Mesquita Filho" - UNESP, Jaboticabal, SP, Brasil
\end{abstract}

How to cite: Braga MSCO, Gonçalves LR, Silva TMV, Costa FB, Pereira JG, Santos LS, et al. Occurrence of Bartonella genotypes in bats and associated Streblidae flies from Maranhão state, northeastern Brazil. Braz J Vet Parasitol 2020; 29(4): e014420. https:// doi.org/10.1590/S1984-29612020088

\begin{abstract}
Bartonella is a genus of emerging zoonotic bacteria that are mainly associated with mammalian erythrocytes and endothelial cells. Bats are natural reservoirs for a variety of important pathogens that impact human and animal health. Recent reports have highlighted the role of bats and bat flies in the maintenance of Bartonella. Here, we showed that none of the 29 bat DNA blood samples obtained from five bat species in São Luís Island, state of Maranhão, northeastern Brazil, were positive for Bartonella in qPCR assays targeting nuoG. On the other hand, three out of 15 DNA samples (20\%) from flies in the family Streblidae were positive for Bartonella. The BLASTn results showed that the $g / t A$ and $r p o B$ sequences shared identities ranging from $97.2 \%$ to $100 \%$, with Bartonella sequences amplified from bats or bat flies from Costa Rica and Brazil. These findings were supported by phylogenetic analyses based on Bayesian inferences. The present study showed that Bartonella genotypes are present in bat flies, thus shedding some light on the distribution of bat fly-related Bartonella genotypes in South America.
\end{abstract}

Keywords: Bartonellosis, Chiroptera, Hippoboscoidea, PCR.

\section{Resumo}

Bartonella é um gênero de bactérias zoonóticas emergentes associadas principalmente a eritrócitos e células endoteliais de mamíferos. Morcegos são reservatórios naturais para uma variedade de patógenos importantes que afetam a saúde humana e animal. Além disso, estudos recentes destacaram o papel dos morcegos e de moscas associadas a morcegos na manutenção de Bartonella. No presente estudo, nenhuma das 29 amostras de DNA obtidas a partir do sangue de cinco espécies de morcegos amostrados na ilha de São Luís, estado do Maranhão, Nordeste do Brasil, foi positiva para Bartonella nos ensaios de qPCR direcionados ao gene nuoG. Por outro lado, três das 15 (20\%) amostras de DNA de moscas da família Streblidae foram positivas para Bartonella. Os resultados do BLASTn mostraram que as sequências dos genes $g / t A$ e $r p o B$ compartilharam identidade, variando de $97,2 \%$ a 100\%, com as sequências de Bartonella amplificadas em morcegos ou moscas amostrados na Costa Rica ou Brasil. Tais resultados corroboraram as análises filogenéticas realizadas por Inferência Bayesiana. O presente estudo mostrou a ocorrência de Bartonella em moscas de morcegos, auxiliando a esclarecer a distribuição dos genótipos de Bartonella relacionadas a moscas Streblidae na América do Sul.

Palavras-chave: Bartonelose, Chiroptera, Hippoboscoidea, PCR. 


\section{Introduction}

The genus Bartonella (Rhizobiales: Bartonellaceae) comprises phylogenetically diverse facultative intracellular Gram-negative a-proteobacteria that mainly infect mammalian erythrocytes and endothelial cells (Eicher \& Dehio, 2012). These bacteria are distributed throughout the world and are transmitted predominantly by blood-feeding arthropods, such as fleas, lice, flies and mosquitoes (Chomel et al., 2009).

Bats play an important role in the maintenance of ecosystem stability. Moreover, this mammal group provides important ecosystem services through pollinating flowers, dispersing seeds and consuming insects. Likewise, bats are recognized as reservoirs or carriers for many zoonotic pathogens (Mühldorfer, 2013).

Bartonella spp. have been reported in over 60 bat species worldwide. In addition, the diversification of bartonellae in bats seems to have followed the diversification of bats, with clustering of bartonellae restricted to single bat families (McKee et al., 2017). Moreover, studies have highlighted the role of bats as reservoirs for zoonotic Bartonella species (Veikkolainen et al., 2014; Bai et al., 2018).

Although the prevalence and genetic diversity of Bartonella have previously been assessed in bats and bat flies around the world (Morse et al., 2012; Bai et al., 2015), several biological aspects of this important bacterial group remain poorly assessed in Brazil. So far, Bartonella DNA has been detected in bats sampled in Brazil with prevalence ranging from 5.28\% (17/322) to 24.51\% (51/208) (Ikeda et al., 2017; Ferreira et al., 2018; André et al., 2019). In addition, Bartonella DNA has been amplified from flies in the family Streblidae (19.8\% [40/202]) collected from bats in Brazil (Amaral et al., 2018). Thus, the current study aimed to verify the occurrence and the phylogenetic positioning of Bartonella in bats and associated flies sampled in northeastern Brazil. Additionally, flies collected from bats were molecularly characterized.

\section{Material and Methods}

Between September and July 2019, 29 bats belonging to five species were trapped in São Luís Island, state of Maranhão, northeastern Brazil (Table 1), during rabies virus surveillance performed by the Agricultural and Livestock Protection Agency of the State of Maranhão (Agência Estadual de Defesa Agropecuária do Maranhão, AGED-MA). These bats were then taken to a field laboratory to determine the species and to verify any presence of ectoparasites. Lastly, the bats were taken still alive in individual bags to the Virology Laboratory of the State University of Maranhão (Universidade Estadual do Maranhão - UEMA) for blood collection. All procedures were carried out according to the ethical guidelines for the use of animal samples permitted by the Institutional Animal Care and Use Committee (IACUC) of UEMA, São Luís, Maranhão (Protocol number: 04/2016).

Table 1. Number and species submitted to Bartonella screening, molecular characterization and BLASTn results.

\begin{tabular}{|c|c|c|c|c|c|}
\hline Sample ID & qPCR & gltA & BLASTn & rpoB & BLASTn \\
\hline Glossophaga soricina & $0 \%(0 / 9)$ & - & - & - & - \\
\hline Carollia perspicillata & $0 \%(0 / 16)$ & - & - & - & - \\
\hline Diaemus youngi & $0 \%(0 / 1)$ & - & - & - & - \\
\hline Pteronotus personatus & $0 \%(0 / 1)$ & - & - & - & - \\
\hline Pteronotus parnellii & $0 \%(0 / 2)$ & - & - & - & - \\
\hline Trichobius spp. & $20 \%(3 / 15)$ & $66 \%(2 / 3)$ & $\begin{array}{l}\text { 99.4\%-100\% Bartonella sp. } \\
\text { (KJ816691 and MH234352) }\end{array}$ & $33 \%(1 / 3)$ & $\begin{array}{l}\text { 97.2\% Bartonella sp. } \\
\text { (MK578352) }\end{array}$ \\
\hline
\end{tabular}

Subsequently, EDTA-blood samples were subjected to DNA extraction using the InstaGene ${ }^{\mathrm{TM}}$ Matrix (Bio-Rad). Additionally, 15 Streblidae flies were individually subjected to DNA extraction using the lllustra Tissue and Cells Genomic Prep Mini Spin kit (GE Healthcare Life Sciences), in accordance with the manufacturer's instructions. To confirm the presence of amplifiable DNA, the DNA samples obtained from the bat blood samples and flies were initially subjected to conventional PCR assays targeting the endogenous mammals-gapdh and insects-cox-1 ( $600 \mathrm{bp})$ genes, respectively (Birkenheuer et al., 2003; Folmer et al., 1994). Endogenous gene-PCR positive DNA samples were subsequently subjected to a previously described broad-range QPCR assay based on the nuoG Bartonella gene 
(André et al., 2016). Finally, the positive DNA samples in the above mentioned screening assay were subjected to conventional PCR assays targeting the gltA (750 bp) and rpoB (825 bp) genes, as previously described (Norman et al., 1995; Renesto et al., 2001).

Thereafter, the amplicons obtained, including insects-associated cox-1, were purified using the EXOSAP-IT® system (Applied Biosystems). Purified amplified DNA fragments were subjected to sequence confirmation in an automatic sequencer (ABI Prism 310 Genetic Analyzer; Applied Biosystems/ Perkin Elmer).

The Bartonella species were identified through BLASTn analysis using Megablast (NCBI, 2020). The phylogenetic analysis was performed using the Bayesian inference method, through MrBayes in XSEDE (3.2.7.a) and was performed in the CIPRES Science Gateway.

\section{Results}

All the bat-blood and fly DNA samples subjected to PCR assays targeting the endogenous mammals-gapdh and insects-cox-1 genes, respectively, were positive. The BLASTn results from seven out of 13 cox-1 fly sequences (two DNA samples showed weak band intensity, which precluded sequencing) shared identities ranging from $88.94 \%$ to $92.91 \%$ with Trichobius parasiticus (MH282310; sampled in Costa Rica). The other five cox-1 fly sequences shared identities ranging from 97.28\% to 97.79\% with Trichobius joblingi (MH282259; sampled in Panama). Lastly, one sequence was $99.04 \%$ similar to Trichobius yunkeri (KY882244; sampled in Mexico).

None of the 29 bat-blood DNA samples were positive in qPCR assays for Bartonella spp. targeting the nuoG gene. On the other hand, three out of 15 DNA samples (20\%) from Streblidae flies were positive for Bartonella (Table 1). The amplified sequences shared identities ranging from $97.2 \%$ to $100 \%$ with sequences previously detected in Carollia perspicillata (MH234352) or bat flies (Trichobius joblingi; KJ816691) from Costa Rica; and in bats (Desmodus rotundus; MK578352) from Brazil (Table 1).

Moreover, and in agreement with phylogenetic analyses, the sequences clustered with other sequences detected in bats and bat flies from the countries mentioned above, and they were supported by high posterior probability values (98\%) in the Bayesian inference analysis (Figure 1 and 2). The sequences amplified in the current study were deposited in GenBank under accession numbers MT275628 and MT275629 for the g/tA gene and MT275630 for the $r p o B$ gene.

\section{Discussion}

Bats and associated ectoparasites have been distinguished as important sources of new Bartonella species/ genotypes (McKee et al., 2017; Sándor et al., 2018). Here, none of the 29 bat blood samples were positive in qPCR assays for Bartonella. In a recent report, André et al. (2019) found high prevalence (24.5\% [51/208]) of Bartonella in vampire bat liver samples from 15 different states in Brazil. However, the three bats caught in the state of Maranhão were negative in real-time PCR assays for Bartonella spp. (André et al., 2019), thus corroborating the results found in the present study.

On the other hand, low prevalence (5.28\% [17/322]) of bartonellae was previously reported in non-hematophagous bats from Brazil that were sampled in the states of São Paulo, Pará, Tocantins and Mato Grosso (Ikeda et al., 2017). These differences in the prevalence of Bartonella in bats may be attributed to distinct factors, such as sample type (e.g., blood, spleen and heart), bat guilds, assay type (e.g. culturing, qPCR assays or conventional PCR assays), number of samples analyzed and distribution of sampled animals.

However, three flies (20\%) that were identified as Trichobius spp. through cox-1 sequencing, were found to be positive for Bartonella. Similar prevalence of Bartonella (19.8\% [40/202]) had previously been reported in Streblidae flies sampled in northeastern Nova Iguaçu, Rio de Janeiro, Brazil (Amaral et al., 2018). On the other hand, high prevalence of Bartonella spp. was reported in bat flies from western Africa (66\%) (Billeter et al., 2012) and Costa Rica (up to 100\%) (Judson et al., 2015). Additional studies aiming to evaluate the factors affecting Bartonella prevalence in bats and associated bat flies are needed.

The presence of amplifiable DNA in the bat blood samples was strikingly evident and was confirmed through an endogenous control PCR assay targeting the mammals-gapdh gene in all the bat samples analyzed. This excluded the possibility of false negative results due to PCR inhibitors. 


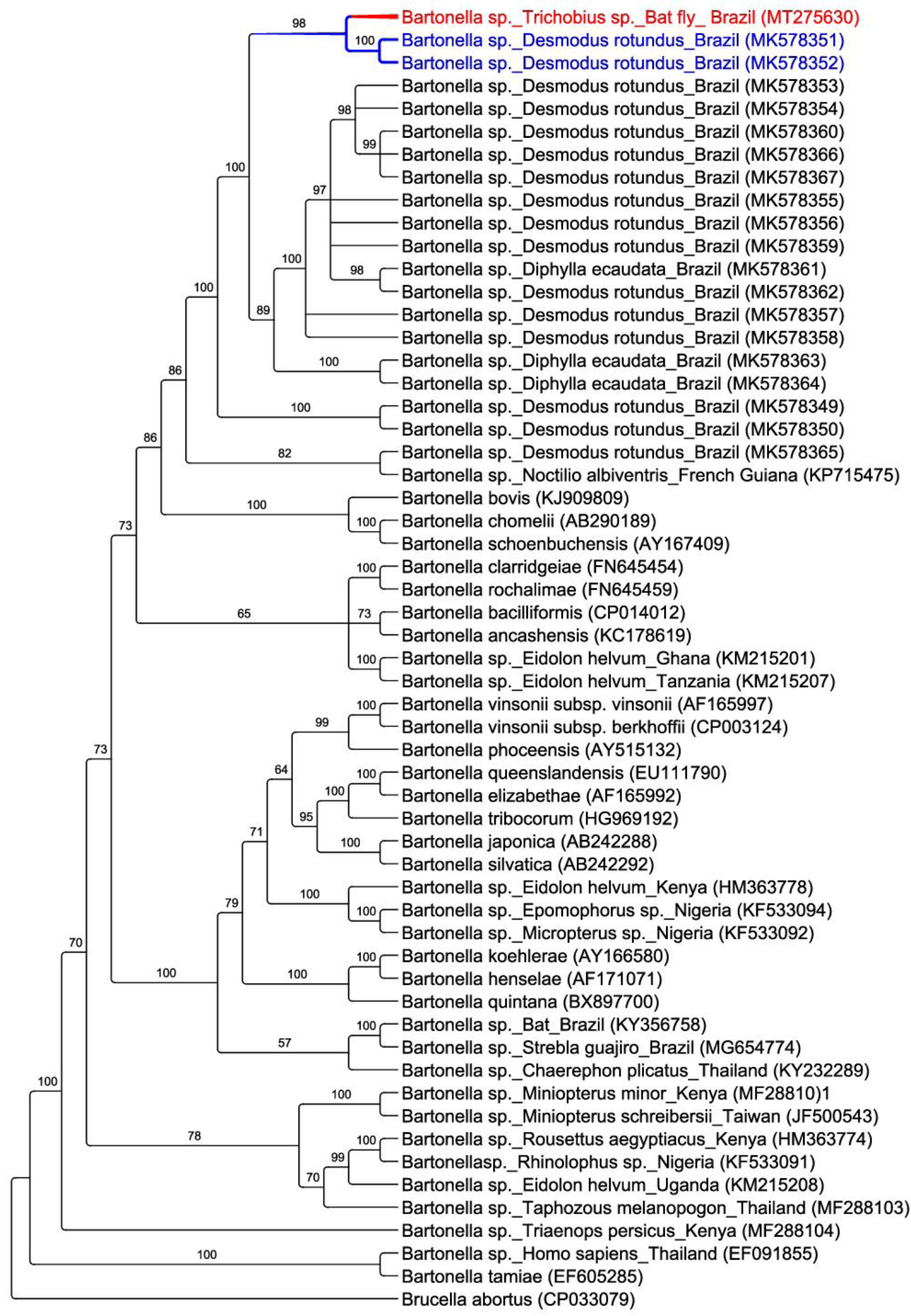

Figure 1. Phylogenetic tree constructed with 800 -bp Bartonella rpoB sequences, using Bayesian method and GTR+G+I evolutionary model. Numbers at nodes correspond to posterior probability over 50\%. Brucella abortus sequence was used as outgroup. The sequence amplified in the current study is highlighted in red. The blue color highlighted sequences belonging to the cluster in which the amplified sequences grouped with. 


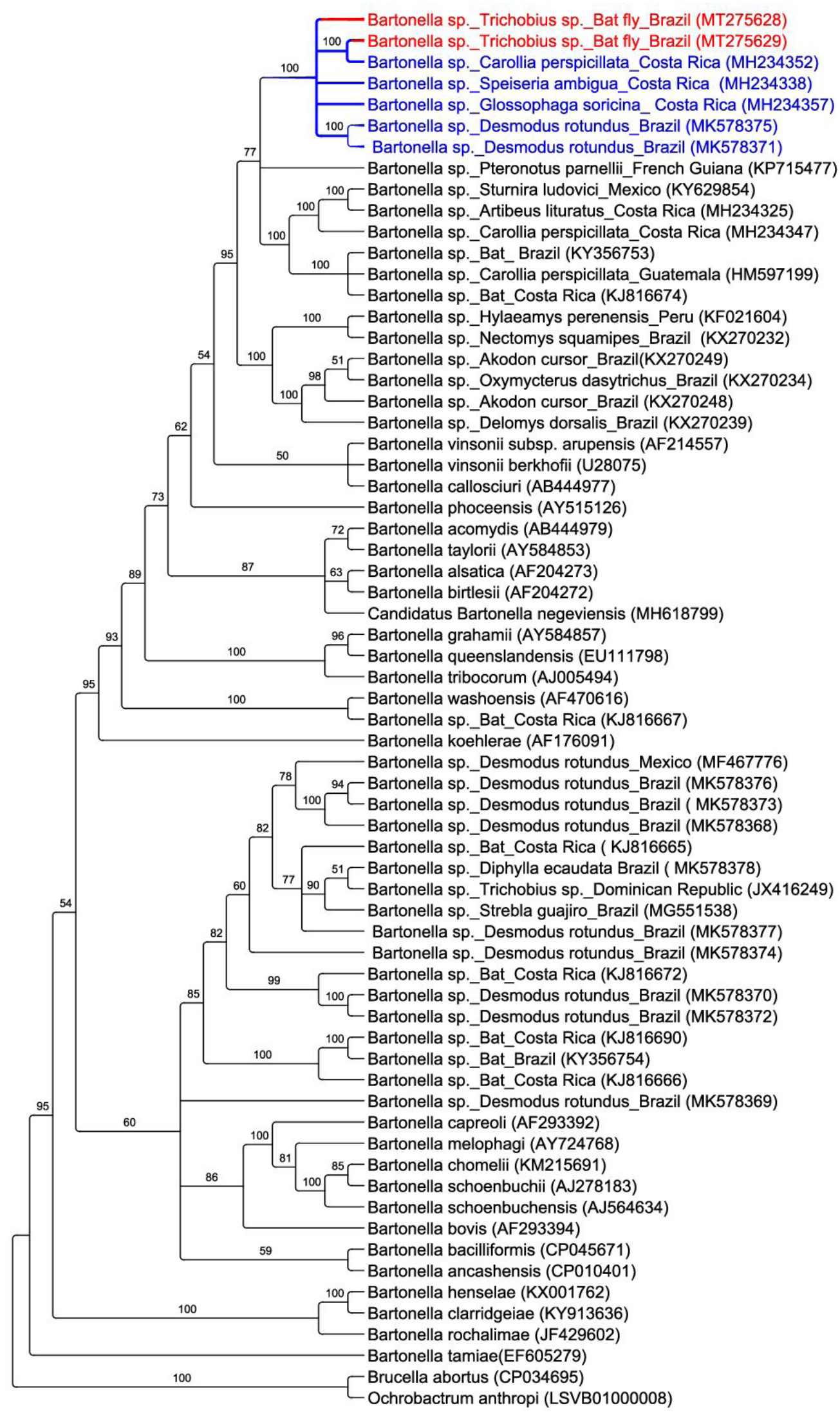

Figure 2. Phylogenetic tree constructed with 700-bp Bartonella g/tA sequences, using Bayesian method and TIM+G+I evolutionary model. Numbers at nodes correspond to posterior probability over 50\%. Ochrobactrum anthropi and Brucella abortus sequences were used as outgroup. The sequences amplified in the current study are highlighted in red. The blue color highlighted sequences belonging to the cluster in which the amplified sequences grouped with. 
Even though none of the bat-blood DNA samples analyzed were positive for Bartonella, three out of the 15 flies were positive in the screening assay. This result can possibly be partially explained by the higher concentration of parasitized red blood cells in the fly's midgut, compared with the erythrocyte levels in the bats' bloodstream.

Interestingly, the gltA and $r p o B$ genotypes detected in Streblidae flies in the present study were shown to be phylogenetically related to those previously detected in bats and bat flies from Brazil and Costa Rica. This highlights the fact that bats and bat fly-related Bartonella genotypes are widespread in Latin America. Further studies are required to elucidate the role of bat flies in the transmission of Bartonella among bat species.

\section{Conclusions}

The present study showed the occurrence of new Bartonella genotypes in Trichobius spp. from northeastern Brazil, despite the absence of bartonellae DNA in the bats that were sampled.

\section{Acknowledgements}

We are grateful to a number of colleagues and students who helped during the bats and bat flies sampling, and to FAPESP (Foundation for Research Support of the State of São Paulo - Process 2018/02753-0) for the financial support. MRA is a fellowship researcher sponsored by CNPq (National Council for Scientific and Technological Development, Process 302420/2017-7).

\section{References}

Amaral RB, Lourenço EC, Famadas KM, Garcia AB, Machado RZ, André MR. Molecular detection of Bartonella spp. and Rickettsia spp. in bat ectoparasites in Brazil. PLoS One 2018; 13(6): e0198629. http://dx.doi.org/10.1371/journal.pone.0198629. PMid:29870549.

André MR, Dumler JS, Herrera HM, Gonçalves LR, de Sousa KC, Scorpio DG, et al. Assessment of a quantitative 5' nuclease real-time polymerase chain reaction using the nicotinamide adenine dinucleotide dehydrogenase gamma subunit (nuoG) for Bartonella species in domiciled and stray cats in Brazil.J Feline Med Surg 2016; 18(10): 783-790. http://dx.doi.org/10.1177/1098612X15593787. PMid:26138812.

André MR, Gutiérrez R, Ikeda P, Amaral RB, de Sousa KCM, Nachum-Biala Y, et al. Genetic diversity of Bartonella spp. in vampire bats from Brazil. Transbound Emerg Dis 2019; 66(6): 2329-2341. http://dx.doi.org/10.1111/tbed.13290. PMid:31287942.

Bai Y, Hayman DTS, McKee CD, Kosoy MY. Classification of Bartonella strains associated with straw-colored fruit bats (Eidolon helvum) across Africa using a multi-locus sequence typing platform. PLoS Neg/ Trop Dis 2015; 9(1): e0003478. http://dx.doi. org/10.1371/journal.pntd.0003478. PMid:25635826.

Bai Y, Osinubi MO, Osikowicz L, McKee C, Vora NM, Rizzo MR, et al. Human exposure to novel Bartonella species from contact with fruit bats. Emerg Infect Dis 2018; 24(12): 2317-2323. http://dx.doi.org/10.3201/eid2412.181204. PMid:30457529.

Billeter SA, Hayman DTS, Peel AJ, Baker K, Wood JLN, Cunningham A, et al. Bartonella species in bat flies (Diptera: Nycteribiidae) from western Africa. Parasitology 2012; 139(3): 324-329. http://dx.doi.org/10.1017/S0031182011002113. PMid:22309510.

Birkenheuer AJ, Levy MG, Breitschwerdt EB. Development and evaluation of a seminested PCR for detection and differentiation of Babesia gibsoni (Asian genotype) and B. canis DNA in canine blood samples. J Clin Microbiol 2003; 41(9): 4172-4177. http:// dx.doi.org/10.1128/JCM.41.9.4172-4177.2003. PMid:12958243.

Chomel BB, Boulouis HJ, Breitschwerdt EB, Kasten RW, Vayssier-Taussat M, Birtles RJ, et al. Ecological fitness and strategies of adaptation of Bartonella species to their hosts and vectors. Vet Res 2009; 40(2): 29. http://dx.doi.org/10.1051/vetres/2009011. PMid:19284965.

Eicher SC, Dehio C. Bartonella entry mechanisms into mammalian host cells. Cell Microbio/ 2012; 14(8): 1166-1173. http://dx.doi. org/10.1111/j.1462-5822.2012.01806.x. PMid:22519749.

Ferreira MS, Guterres A, Rozental T, Novaes RLM, Vilar EM, Oliveira RC, et al. Coxiella and Bartonella spp. in bats (Chiroptera) captured in the Brazilian Atlantic Forest biome. BMC Vet Res 2018; 14(1): 279. http://dx.doi.org/10.1186/s12917-018-1603-0. PMid:30200947.

Folmer O, Black M, Hoeh W, Lutz R, Vrijenhoek R. DNA primers for amplification of mitochondrial cytochrome c oxidase subunit I from diverse metazoan invertebrates. Mol Mar Biol Biotechnol 1994; 3(5): 294-299. PMid:7881515. 
Ikeda P, Seki MC, Carrasco AOT, Rudiak LV, Miranda JMD, Gonçalves SMM, et al. Evidence and molecular characterization of Bartonella spp. and hemoplasmas in neotropical bats in Brazil. Epidemiol Infect 2017; 145(10): 2038-2052. http://dx.doi.org/10.1017/ S0950268817000966. PMid:28502279.

Judson SD, Frank HK, Hadly EA. Bartonellae are prevalent and diverse in Costa Rican bats and bat flies. Zoonoses Public Health 2015; 62(8): 609-617. http://dx.doi.org/10.1111/zph.12188. PMid:25810119.

McKee CD, Kosoy MY, Bai Y, Osikowicz LM, Franka R, Gilbert AT, et al. Diversity and phylogenetic relationships among Bartonella strains from Thai bats. PLoS One 2017; 12(7): e0181696. http://dx.doi.org/10.1371/journal.pone.0181696. PMid:28727827.

Morse SF, Olival KJ, Kosoy M, Billeter S, Patterson BD, Dick CW, et al. Global distribution and genetic diversity of Bartonella in bat flies (Hippoboscoidea, Streblidae, Nycteribiidae). Infect Genet Evol 2012; 12(8): 1717-1723. http://dx.doi.org/10.1016/j. meegid.2012.06.009. PMid:22771358.

Mühldorfer K. Bats and bacterial pathogens: a review. Zoonoses Public Health 2013; 60(1): 93-103. http://dx.doi.org/10.1111/j.18632378.2012.01536.x. PMid:22862791.

National Center for Biotechnology Information - NCBI. BLAST: Basic Local Alignment Search Tool [online]. Bethesda: NCBI; 2020 [cited 2020 June 15]. Available from: https://blast.ncbi.nlm.nih.gov/

Norman AF, Regnery R, Jameson P, Greene C, Krause DC. Differentiation of Bartonella-like isolates at the species level by PCRrestriction fragment length polymorphism in the citrate synthase gene. J Clin Microbiol 1995; 33(7): 1797-1803. http://dx.doi. org/10.1128/JCM.33.7.1797-1803.1995. PMid:7545181.

Renesto P, Gouvernet J, Drancourt M, Roux V, Raoult D. Use of rpoB gene analysis for detection and identification of Bartonella species. J Clin Microbiol 2001; 39(2): 430-437. http://dx.doi.org/10.1128/JCM.39.2.430-437.2001. PMid:11158086.

Sándor AD, Földvári M, Krawczyk Al, Sprong H, Corduneanu A, Barti L, et al. Eco-epidemiology of novel Bartonella genotypes from parasitic flies of insectivorous bats. Microb Ecol 2018; 76(4): 1076-1088. http://dx.doi.org/10.1007/s00248-018-1195-z. PMid:29705820.

Veikkolainen V, Vesterinen EJ, Lilley TM, Pulliainen AT. Bats as reservoir hosts of human bacterial pathogen, Bartonella mayotimonensis. Emerg Infect Dis 2014; 20(6): 960-967. http://dx.doi.org/10.3201/eid2006.130956. PMid:24856523. 